Int. J. Electrochem. Sci., 12 (2017) 386 - 395

International Journal of

ELECTROCHEMICAL

SCIENCE

WWW.electrochemsci.org

\title{
Synthesis and Electrochemical Properties of $0^{0.7} \mathrm{LiMn}_{0.71} \mathrm{Fe}_{0.29} \mathrm{PO}_{4} \cdot \mathrm{O}_{3} 3 \mathrm{Li}_{3} \mathrm{~V}_{2}\left(\mathrm{PO}_{4}\right)_{3} / \mathrm{C}$ Composite as High- Performance Cathode Materials for Lithium-Ion Batteries
}

\author{
XinYu Wang ${ }^{1}$, Zhi Su ${ }^{l, *}$, ShanShan $\mathrm{Li}^{2}$ \\ ${ }^{1}$ College of Chemistry and Chemical Engineering, Xinjiang Normal University, Urumqi 830054, \\ Xinjiang, China \\ ${ }^{2}$ Bayingol Vocational and Technical College, Korla 841000, Xinjiang, China \\ *E-mail: suzhixj@sina.com
}

doi: $10.20964 / 2017.01 .67$

Received: 7 September 2016 / Accepted: 23 November 2016 / Published: 12 December 2016

\begin{abstract}
A new polyanionic composite cathode materials, 0.7 $\mathrm{LiMn}_{0.71} \mathrm{Fe}_{0.29} \mathrm{PO}_{4} \cdot 0.3 \mathrm{Li}_{3} \mathrm{~V}_{2}\left(\mathrm{PO}_{4}\right)_{3} / \mathrm{C}$, was synthesized using a novel sol-gel method and with $N, N$-dimethyl formamide (DMF) as solvent. X-ray diffraction and transmission electron microscopy results indicated that the composite material was well-crystallized and a conductive carbon matrix surrounded the $0.7 \mathrm{LiMn}_{0.71} \mathrm{Fe}_{0.29} \mathrm{PO}_{4} \cdot 0.3 \mathrm{Li}_{3} \mathrm{~V}_{2}\left(\mathrm{PO}_{4}\right)_{3} / \mathrm{C}$ particles of grain size $20-50 \mathrm{~nm}$. Elements $\mathrm{Mn}, \mathrm{V}$, and $\mathrm{Fe}$ in the composite were confirmed to be in $+2,+3$, and +2 valence states, respectively, by X-ray photoelectron spectroscopy. Electrochemical tests showed that as a cathode material, $0.7 \mathrm{LiMn}_{0.71} \mathrm{Fe}_{0.29} \mathrm{PO}_{4} \cdot 0.3 \mathrm{Li}_{3} \mathrm{~V}_{2}\left(\mathrm{PO}_{4}\right)_{3} / \mathrm{C}$ exhibited the best reversible capacities of $152.5,130.1,123.6$, 109.5 , and $83.6 \mathrm{mAh} \cdot \mathrm{g}^{-1}$ at charge/discharge rates of $0.05,0.1,0.2,0.5$, and $1 \mathrm{C}$, respectively. It also retained $147.2 \mathrm{mAh} \cdot \mathrm{g}^{-1}(91.8 \%)$ capacity in the Li-ion battery after 50 cycles at $0.05 \mathrm{C}$.
\end{abstract}

Keywords: lithium-ion cathode materials ; composite; sol-gel; nanoparticle; electrochemical properties

\section{$\underline{\text { FULL TEXT }}$}

(C) 2017 The Authors. Published by ESG (www.electrochemsci.org). This article is an open access article distributed under the terms and conditions of the Creative Commons Attribution license (http://creativecommons.org/licenses/by/4.0/). 